\title{
UJI DAYA HAMBAT EKSTRAK ETANOL DAUN SANGKAREHO (Callicarpa longifolia Lam.) TERHADAP Escherichia coli
}

\author{
Rezqi Handayani ${ }^{1,}$ Gabrile Natasia ${ }^{2}$
}

\author{
1Dosen Program Studi D-III Farmasi Universitas Muhammadiyah Palangkaraya \\ ${ }^{2}$ Mahasiswa Program Studi D-III Farmasi Fakultas IImu Kesehatan Universitas Muhammadiyah \\ Palangkaraya
}

Email : rezqi.handayani@gmail.com,

\begin{abstract}
ABSTRAK
Tanaman obat adalah salah satu diantara obat tradisional yang paling banyak digunakan secara empiris oleh masyarakat dalam rangka menanggulangi masalah kesehatan yang dihadapinya, baik dengan maksud pemeliharaan, pengobatan, maupun pemilihan kesehatan. Salah satu tanaman dari Puruk Cahu yang dapat digunakan sebagai obat tradisional serta banyak khasiatnya adalah daun Sangkareho (Callicarpa longifolia Lam.). Berdasarkan hasil penelitian Akhmad Khadafi S. (2016), pada daun Sangkareho (Callicarpa longifolia Lam.) terkandung beberapa zat aktif seperti flavonoid, steroid, alkaloid, dan tanin. Berdasarkan data empiris masyarakat Puruk Cahu, daun Sangkareho (Callicarpa longifolia Lam.) mempunyai khasiat dan dimanfaatkan sebagai obat tradisional untuk mengobati penyakit diare. Salah satu bakteri yang menjadi pemicu diare adalah bakteri Escherichia coli.

Penelitian ini bertujuan untuk mengetahui kemampuan daya hambat ekstrak daun Sangkareho yang digunakan sebagai obat tradisional untuk mengobati diare yang disebabkan oleh bakteri Escherichia coli serta untuk konsenstrasi ekstrak daun Sangkareho yang mampu menghambat pertumbuhan bakteri Escherichia coli.

Penelitian ini dilakukan di Laboratorium Mikrobiologi Fakultas IImu Kesehatan Universitas Muhammadiyah Palangkaraya. Kegiatan penelitian yang dilakukan adalah ekstraksi daun Sangkareho (Callicarpa longifolia Lam.) dan uji daya hambat ekstrak etanol daun Sangkareho (Callicarpa longifolia Lam.) terhadap pertumbuhan bakteri Escherichia coli.

Hasil yang didapat dari penelitian ini adalah ekstrak daun Sangkareho menunjukkan bahwa tidak ada respon hambatan terhadap pertumbuhan bakteri Escherichia coli. Antibiotik Cotrimoxazole sebagai kontrol positif mampu menghambat pertumbuhan bakteri Escherichia coli pada semua konsentrasi. Rata-rata diameter zona hambat Cotromoksazole pada konsentrasi $1 \%$ sebesar $7,7 \mathrm{~mm}$, pada konsentrasi $5 \%$ sebesar $16,3 \mathrm{~mm}$, pada konsentrasi $10 \%$ sebesar $18,4 \mathrm{~mm}$, dan pada konsentrasi $15 \%$ sebesar $20,6 \mathrm{~mm}$. Sedangkan untuk diameter zona hambat ekstrak daun Sangkareho pada semua konsentrasi di dapatkan $0 \mathrm{~mm}$.
\end{abstract}

Kata Kunci : Daun Sangkareho (Callicarpa Iongifolia Lam.), Uji daya hambat, Escherichia coli 


\section{PENDAHULUAN}

Obat tradisional menurut UndangUndang Republik Indonesia Nomor 39 Tahun 2009 tentang Kesehatan merupakan bahan atau ramuan yang berupa bahan tumbuhan, bahan hewan, bahan mineral, sediaan sarian (galenik) atau campuran dari bahan tersebut secara umum turun menurun telah digunakan untuk pengobatan dan dapat diterapkan sesuai dengan norma yang berlaku di masyarakat. Obat tradisional di Indonesia sangat besar peranannya dalam pelayanan kesehatan masyarakat di Indonesia, sehingga obat tradisional sangat berpotensi untuk dikembangkan. Indonesia kaya akan tanaman obat-obatan, yang mana masih belum dimanfaatkan secara optimal untuk kesehatan. Obat tradisional merupakan warisan budaya bangsa yang perlu terus dilestarikan dan dikembangkan untuk menunjang pembangunan kesehatan sekaligus untuk meningkatkan perekonomian rakyat (Notoatmodjo, 2007).

Kemajuan teknologi dan ilmu pengetahuan modern yang semakin pesat dan canggih di zaman sekarang ini ternyata tidak mampu menggeser atau mengesampingkan begitu saja obat tradisional, tetapi justru hidup berdampingan dan saling melengkapi. Hal ini terbukti dan banyaknya peminat pengobatan tradisional. Namun yang menjadi masalah dan kesulitan bagi para peminat obat tradisional adalah kurangnya pengetahuan dan informasi yang memadai mengenai berbagai jenis tumbuhan dipakai sebagai obat tradisional untuk pengobatan penyakit tertentu (Dalimartha, 2000).

Prospek pengembangan produksi tanaman obat semakin pesat, mengingat perkembangan industri obat modern dan obat tradisional terus meningkat. Kondisi ini terus dipengaruhi oleh kesadaran masyarakat yang semakin meningkat tentang manfaat tanaman sebagai obat. Masyarakat semakin sadar akan pentingnya kembali ke alam (back to nature) dengan memanfaatkan obat-obat alami. Memang obat modern berkembang cukup pesat, namun potensi obat tradisional terutama yang berasal dari tumbuhan tetap tinggi. Hal ini disebabkan obat tradisional dapat diperoleh tanpa resep dokter, dapat diramu sendiri, bahan baku tidak perlu diimpor, dan tanaman obat dapat ditanam sendiri oleh peamakainya (Djauhariya dan Hernani, 2004).

Penggunaan obat tradisional secara luas oleh masyarakat disebabkan selain karena alami, mudah didapat, serta harganya murah, penggunaan obat ramuan tumbuhan secara tradisional ini tidak menghasilkan efek samping yang ditimbulkan seperti yang sering terjadi pada pengobatan secara kimiawi, selain itu masih banyak orang yang beranggapan bahwa penggunaan obat tradisional lebih aman 
Rezqi Handayani dan Gabrile Natasia

dibandingkan dengan obat sintesis

(Thomas, 1989).

Pengobatan tradisional khususnya yang menggunakan tanaman obat, tetap berlangsung di zaman modern ini, bahkan cenderung meningkat. Salah satu faktornya disebabkan karena pada penggunaan obatobatan modern dapat menimbulkan berbagai macam efek samping, diantaranya seperti : hiperasiditas lambung dan penurunan tekanan darah yang terjadi secara mendadak. Pemberian obat-obatan tradisional merupakan salah satu cara pencegahan dari penyakit infeksi, baik yang disebabkan oleh bakteri maupun jamur. Obat tradisional/herbal banyak digunakan masyarakat karena hasilnya yang paten meskipun khasiatnya dapat dirasakan dalam jangka waktu cukup lama serta tanpa adanya efek samping (Meira, 2014).

Indonesia kaya akan sumber daya alam khususnya sumber daya hayati yang meliputi berbagai jenis tumbuhan. Dari 40.000 jenis tumbuhan yang tumbuh di Indonesia, hampir 1.000 jenis diantaranya dapat digunakan sebagai bahan obat tradisional (Sarson, et al., 2014). Kekayaan hayati ini tersebar di pulau-pulau besar Indonesia, salah satunya di pulau Kalimantan banyak terdapat tanaman yang dapat dijadikan bahan obat tradisional, khususnya Kalimantan Tengah yang termasuk salah satu kawasan dengan banyak menyimpan keanekaragaman hayati yang sudah dimanfaatkan oleh masyarakat setempat sejak puluhan tahun lamanya untuk pengobatan. Penggunaan obat tradisional di Kalimantan Tengah semakin diminati masyarakat karena khasiatnya diyakini tidak kalah dengan obat-obatan produksi pabrikan. Sebagian masyarakat Kalimantan Tengah ada yang hidup terpencil, jauh dari jangkauan pengobatan modern, dalam usaha menjaga dan mepertahankan kesehatan, masyarakat menggunakan obat tradisional yang diramu dari bahan alam tanaman tersebut. Tanaman obat adalah salah satu diantara obat tradisional yang paling banyak digunakan secara empiris oleh masyarakat dalam rangka menanggulangi masalah kesehatan yang dihadapinya, baik dengan maksud pemeliharaan, pengobatan, maupun pemilihan kesehatan (Hembing, 2003). Salah satu tanaman dari Kalimantan Tengah yang dapat digunakan sebagai obat tradisional serta banyak khasiatnya adalah daun Sangkareho (Callicarpa longifolia Lam.). Daun Sangkareho (Callicarpa longifolia Lam.) digunakan masyakarat setempat sebagai obat untuk mengobati luka, pasca pendarahan setelah melahirkan, dan diare.

Berdasarkan hasil penelitian Akhmad Khadafi S. (2016), pada daun Sangkareho (Callicarpa longifolia Lam.) terkandung beberapa zat aktif seperti flavonoid, alkaloid, dan steroid. 
Uji Daya Hambat Ekstrak Etanol Daun Sangkareho (Callicarpa longifolia Lam.) Terhadap

Escherichia coli

Berdasarkan data empiris masyarakat Puruk Cahu, daun Sangkareho (Callicarpa longifolia Lam.) mempunyai khasiat dan dimanfaatkan sebagai obat tradisional untuk mengobati penyakit diare. Diare umumnya disebabkan oleh infeksi virus, protozoa; (Giardia lambdia, Entamoeba hystolitica), bakteri; yang memproduksi enterotoksin (Staphylococcus aureus, Clostridium perfringen), Escherichia coli, Vibrio cholera, Clostridium difficile dan yang menimbulkan inflamasi mukosa usus (Shigella sp., Salmonella sp., Yersinia) (Djojoningrat, 2006). Salah satu bakteri yang menjadi pemicu diare adalah bakteri Escherichia coli (Sinthamurniwati, 2006).

\section{METODELOGI PENELITIAN}

Penelitian ini dilaksanakan di laboratorium Mikrobiologi

dan Farmakognosi Fakultas IImu Kesehatan Universitas Muhammadiyah Palangkaraya. Waktu penelitian ini selama 3 bulan, kegiatan penelitian ini dimulai dari pengambilan tumbuhan Kelakai, pembuatan ekstrak dan uji daya hambat ekstrak etanol daunSangkareho(Callicarpa longifolia Lam.) terhadap bakteri Escherichia coli.

\section{PembuatanEkstrak}

Pembuatan ekstrak daun Sangkareho (CallicarpalongifoliaLam.) denganmetodeperkolasi dilakukan dengan caraMenimbang serbuk simplisia daun Sangkareho (CallicarpalongifoliaLam.) sebanyak 300 gram.Memasukkan serbuk

simplisia daun Sangkareho
(CallicarpalongifoliaLam.) ke dalam perkolator. Menambahkan pelarut etanol hingga serbuk terendam dalam pelarut berada $2 \mathrm{~cm}$ di atas serbuk, kemudian menutup perkolator sambil sesekali diaduk. Rendam selama 3 kali 24 jam sambil dilakukan pengadukan dan setiap 24 jam dilakukan penyaringan. Mengambil ekstrak cair yang didapat dan ekstrak tersebut di evaporasi menggunakan evaporator hingga kadar etanol berkurang setengahnya. Menguapkan ekstrak tersebut di atas waterbath menggunakan cawan porselin pada suhu $95^{\circ} \mathrm{C}$ hingga diperoleh ekstrak kental. Selanjutnya menimbang ekstrak kental yang didapat.

Uji Daya Hambat

Uji daya hambat ekstrak daun Sangkareho terhadap Escherichia coli dilakukan sebagai berikut :beberapa koloni isolat Escherichia coli diambil lalu di kultur ke media Mueller Hinton Agar (MHA) dengan cara di oleskan di permukaan agar yang telah mengeras. Media yang telah di oles bakteri, diatasnya diletakkan kertas cakram/disk yang telah direndam di dalam larutan ekstrak daun Sangkareho dengan konsentrasi $1 \%$, konsentrasi $5 \%$, konsentrasi 10\%, dan konsentrasi $15 \%$, serta antibiotik Cotrimoxazole sebagai kontrol positif dengan konsentrasi yang sama seperti konsentrasi ekstrak daun Sangkareho. Selanjutnya, diinkubasi 
Rezqi Handayani dan Gabrile Natasia

selama 24 jam pada suhu $37^{\circ} \mathrm{C}$. Zona

hambat yang terbentuk dari masing-masing kertas cakram/disk diukur menggunakan jangka sorong.

\section{HASIL DAN PEMBAHASAN}

\section{Pembuatan Ekstrak Daun Sangkareho}

Metode yang digunakan untuk memperoleh ekstrak daun Sangkareho adalah metode perkolasi. Menurut Parameter Standar Umum Ekstrak Tumbuhan Obat, perkolasi adalah ekstraksi dengan pelarut yang selalu baru sampai sempurna (exhaustive extraction) yang umumnya dilakukan pada temperatur ruangan. Proses terdiri dari tahapan pengembangan bahan, tahap maserasi antara, tahap perkolasi sebenarnya (penetesan/penampungan ekstrak), terus menerus sampai diperoleh ekstrak (perkolat) yang jumlahnya 1-5 kali bahan. Ekstrak cair yang diperoleh kemudian evaporasi dan dikentalkan dengan menggunakan waterbath. Metode ini digunakan karena cara perkolasi mudah dan sederhana dilakukan, serta peluang resiko pengotor sangat kecil.

\section{Uji Daya Hambat Daun Sangkareho terhadap Bakteri E.Coli}

Hasil pengujian daya hambat kontrol positif obat Cotrimoxazole terhadap pertumbuhan bakteri Escherichia coli yang diperoleh dapat dilihat pada Tabel 1 dibawah ini :

Tabel 1.Hasil uji daya hambat kontrol positif obat Cotrimoxazole terhadap bakteri Escherichia coli

\begin{tabular}{cccccc}
\hline \multirow{2}{*}{ Konsentrasi } & \multicolumn{3}{c}{ Diameter zonahambat $(\mathbf{m m})$} & Rata-rata & Keterangan \\
\cline { 2 - 4 } & Percobaa & Percobaan & Percobaan & $\mathbf{( m m )}$ & \\
\hline $1 \%$ & $\mathbf{n ~ 1}$ & $\mathbf{2}$ & $\mathbf{3}$ & & \\
\hline $5 \%$ & 17,4 & 17,7 & 13,9 & 16,3 & Susceptible \\
$10 \%$ & 19,5 & 18,2 & 17,5 & 18,4 & Susceptible \\
$15 \%$ & 21,5 & 20,6 & 19,7 & 20,6 & Susceptible \\
\hline
\end{tabular}

Sedangkan hasil pengujian daya hambat ekstrak daun Sangkareho terhadap pertumbuhan bakteri Escherichia coli yang diperoleh dapat dilihat pada Tabel 2 dibawah ini : 
Uji Daya Hambat Ekstrak Etanol Daun Sangkareho (Callicarpa longifolia Lam.) Terhadap

Escherichia coli

Tabel 2. Hasil uji daya hambat ekstrak daun Sangkareho terhadap bakteri Escherichia coli

\begin{tabular}{|c|c|c|c|c|c|}
\hline \multirow{2}{*}{ Konsentrasi } & \multicolumn{3}{|c|}{ Diameter zonahambat (mm) } & \multirow{2}{*}{$\begin{array}{l}\text { Rata- } \\
\text { rata } \\
(\mathrm{mm})\end{array}$} & \multirow[b]{2}{*}{ Keterangan } \\
\hline & Percobaan 1 & Percobaan 2 & Percobaan 3 & & \\
\hline $1 \%$ & Tidak ada & Tidak ada & Tidak ada & $\begin{array}{c}\text { Tidak } \\
\text { ada }\end{array}$ & Rendah \\
\hline $5 \%$ & Tidak ada & Tidak ada & Tidak ada & $\begin{array}{c}\text { Tidak } \\
\text { ada }\end{array}$ & Rendah \\
\hline $10 \%$ & Tidak ada & Tidak ada & Tidak ada & $\begin{array}{c}\text { Tidak } \\
\text { ada }\end{array}$ & Rendah \\
\hline $15 \%$ & Tidak ada & Tida ada & Tidak ada & $\begin{array}{c}\text { Tidak } \\
\text { ada }\end{array}$ & Rendah \\
\hline
\end{tabular}

Hasil uji daya hambat ekstrak daun Sangkareho dan kontrol positif antibiotik Cotrimoxazole terhadap bakteri Escherichia coli diperoleh melalui pengamatan yang dilakukan dengan 3 kali pengulangan. Kepekaan bakteri terhadap antibiotik atau bahan anti bakteri dapat diamati dengan terbentuknya zona hambat (daerah bening di sekeliling sumur) (Kairupan, et al., 2014). Menurut Oroh, Stery B., et al (2014), daya hambat ekstrak yang diuji ditunjukkan dengan adanya zona bening di sekitar kertas cakram. Zona bening di sekitar kertas cakram merupakan daerah difusi ekstrak yang mempengaruhi pertumbuhan bakteri. Besar diameter dari zona hambat yang terbentuk dapat menunjukkan kekuatan anti bakteri dari ekstrak yang digunakan.

Pengujian untuk kontrol positif menggunakan antibiotik spektrum luas yaitu
Cotrimoxazole. Cotrimoxazole adalah sediaan kombinasi tetap trimetoprim dan sulfametoksazol dengan perbandingan $1: 5$ yang mempunyai aktivitas bakterisida. Antibiotik Cotrimoxazole dapat digunakan untuk mengobati berbagai infeksi, salah satunya adalah infeksi saluran pencernaan seperti diare yang disebabkan oleh bakteri Escherichia coli. Pengujian ini dilakukan dengan perlakuan yang sama seperti ekstrak daun Sangkareho yang menggunakan antibiotik Cotrimoxazole dengan konsentrasi $1 \%, 5 \%, 10 \%$, dan $15 \%$. Menurut standar CLSI (Clinical and Laboratory Standart Institute), zona diameter antibiotik Cotrimoxazole (Trimethoprim-Sulfamethoxazole) terhadap bakteri Escherichia coli adalahResistant $\leq 10$ $\mathrm{mm}$, Intermediate 11-15 $\mathrm{mm}$, dan Susceptible $\geq 16 \mathrm{~mm}$. 
Berdasarkan dari hasil penelitian, antibiotik Cotrimoxazole mampu menghambat pertumbuhan bakteri Escherichia coli pada semua konsentrasi. Rata-rata diameter zona hambat pada konsentrasi $1 \%$ sebesar $7,7 \mathrm{~mm}$, pada konsentrasi $5 \%$ sebesar $16,3 \mathrm{~mm}$, pada konsentrasi $10 \%$ sebesar $18,4 \mathrm{~mm}$, dan pada konsentrasi $15 \%$ sebesar 20,6 mm. Tujuan uji pengamatan terhadap kontrol positif ini dilakukan untuk membuktikan bahwa pada media Mueller Hinton Agar (MHA) yang digunakan pada pengujian ekstrak daun Sangkareho terdapat adanya pertumbuhan bakteri Escherichia coli (Fitriani, 2011). Escherichia coli merupakan bakteri gram negatif yang dapat dihambat oleh Cotrimoxazole yang merupakan antibiotik dengan spektrum luas.

Berdasarkan dari hasil penelitian yaitu penanaman disk ekstrak daun Sangkareho pada media Mueller Hinton Agar (MHA) yang berisikan bakteri Escherichia coli tidak mampu menghambat pertumbuhan bakteri Escherichia coli baik dari konsentrasi $1 \%, 5 \%, 10 \%$, maupun 15\%. Rata-rata diameter zona hambat ekstrak daun Sangkareho baik pada konsentrasi $1 \%, 5 \%, 10 \%$, dan $15 \%$ yaitu 0 $\mathrm{mm}$, yang dibandingkandengantabel Pan Chen Wu Tang and Zhao (2009) maka termasuk respon hambatannya yaitu rendah (0-3 mm). Hasil pengujian daya hambat ekstrak daun Sangkareho menunjukkan bahwa respon hambatannya rendah terhadap pertumbuhan bakteri Escherichia coli. Hal ini dapat disebabkan karena pada konsentrasi ini, zat aktif yang berperan sebagai anti bakteri pada ekstrak tanaman uji ini jumlahnya sedikit sehingga belum dapat menghambat aktivitas pertumbuhan bakteri Escherichia coli (Sulastrianah, et al., 2014). Hal ini kemungkinan disebabkan oleh beberapa faktor yaitu bakteri Escherichia coli tidak sensitif terhadap ekstrak daun Sangkareho atau kemungkinan ekstrak daun Sangkarehod apatmenghambat pertumbuhan bakteri lain, serta kurang tepatnya pemilihan konsentrasi yang digunakan dalam pengujian daya hambat ekstrak daun Sangkareho terhadap pertumbuhan bakteri Escherichia coli.

\section{KESIMPULAN}

Berdasarkan dari hasil penelitian yang telah dilakukan, dapat disimpulkan sebagai berikut :

1. Ekstrak daun Sangkareho dengan konsentrasi $1 \%$, 5\%, $10 \%$, dan $15 \%$ tidak mampu menghambat pertumbuhan bakteri Escherichia coli sehingga hasil yang didapatya itu negatif.

2. Pada konsentrasi 1\%, 5\%, 10\%, maupun 15\% ekstrak daun Sangkareho tidak terdapat zona hambat terhadap pertumbuhan bakteri Escherichia coli. 
Uji Daya Hambat Ekstrak Etanol Daun Sangkareho (Callicarpa Iongifolia Lam.) Terhadap

Escherichia coli

\section{DAFTAR PUSTAKA}

Clinical Laboratory Standart Institute. 2013.

Performance Standart for

Antimicrobial Susceptibility Testing;

Twentieth Information Supplement.

USA..

Dalimartha, S. 2000. Atlas Tumbuhan Obat Indonesia Jilid I. Jakarta : Trubus Agriwidya.

Djauhariyah, E., dan Hernani. 2004. Gulma Berkhasiat Obat. Jakarta : Seri Agrisehat.

Djojoningrrat. 2006. Buku Ajar Ilmu Penyakit Dalam : Dispepsia Fungsional. Jakarta : Penerbit Buku Kedokteran EGC.

Hembing. 2003. dalam Latar Belakang. Bandung : Fakultas Kedokteran Universitas Kristen Maranatha.

Kairupan, Christy Priskila; Fatimawali; A. Lolo, Widya. 2014. Uji Daya Hambat Ekstrak Etanol Daun Kembang Sepatu (Hibiscus rosa-sinensis L) Terhadap Pertumbuhan Bakteri Escherichia coli. Manado : Jurnal Ilmiah Farmasi Universitas Sam Ratulangi.

Meira, Raina. 2014. Latar Belakang. Semarang : Universitas Muhammadiyah Semarang.
Notoatmodjo, S. 2007. Promosi Kesehatan dan IImu Perilaku. Jakarta : Rineka Cipta.

Pan Chen Wu Tang and Zhao. 2009. Klasifikasi Respon Hambatan Ekstrak Terhadap Pertumbuhan Bakteri dalam Artikel Penelitian Rezqi Handayani. 2016. "Uji Daya Hambat Ekstrak Metanol dan Fraksi Rimpang Lengkuas Merah (Alipinia purpuruta $K$ Schoum) Terhadap Bakteri Escheria coli". Palangkaraya : Jurnal Surya Medika Volume 1 No.2.

Saputra, Akhmad Khadafi. 2016. Uji Identifikasi Farmakognostik Tanaman Sangkareho (Callicarpa Iongifolia Lam.) Asal Kalimantan Tengah. Palangkaraya : Karya Tulis Ilmiah Universitas Muhammadiyah Palangkaraya.

Sarson, Moh. Rizki S.; Wuisan, Jane; Awaloei, Henoch. 2014. Uji Daya Hambat Ekstrak Daun Bawang Merah (Allium cepa L.) Terhadap Pertumbuhan Bakteri Escherichia coli. Manado : Bagian Farmakologi Fakultas Kedokteran Sam Ratulangi.

Sinthamurniwati. 2006. Faktor-Faktor Risiko Kejadian Diare Akut Pada Balita. Semarang : Tesis UNDIP.

Thomas, A. N. S. 1989. Tanaman Obat Tradisional. Yogyakarta : Kanisius. 